\title{
Analyzing The Determinants Of Attitude, Behavior, And Satisfaction On Imported Products: Implications For The Growing Food And Beverage Industry
}

\author{
Alexander James McSporran, Graduate, KDI School of Public Policy and Management, South Korea
} Yoon C. Cho, KDI School of Public Policy and Management, South Korea

\begin{abstract}
The aims of this study are to determine the influences of attitude formation, behavior, and satisfaction, with specific reference to the products of the food and beverage industry of Southeast Asia. This study employs the theoretical frameworks of the Theory of Planned Behavior and others to understand the psychological processes that take place between forming beliefs and actual consumption. The key findings reveal that consumers are influenced by both the traditional food attributes such as quality, price, and availability, while also extraneously influenced both by perceived family influence and perceived societal influence in their attitude formation. These factors, through the proposed model of study, were also statistically proven to influence behavioral intention of the sample group through willingness to purchase. In addition, satisfaction with prior purchase was also shown to be a determinant of consumer attitude, while the determinants of expected satisfaction were inconclusive. The results of the modelling and analyses of this study indicate the necessity for the concurrent development of innovative marketing strategies and quality improvements in the industry as it follows its projected growth course and outward expansion.
\end{abstract}

Keywords: Attitude; Behavior; Satisfaction; Food and Beverage Industry

\section{INTRODUCTION}

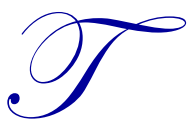
he Food and Beverage (F\&B) industry encompasses all companies involved in the processing of raw food materials, packaging, and distribution. Any product meant for human consumption, aside from pharmaceuticals, passes through this industry. While no course of economic development is the same, worldwide consumer studies have noted that with growth of income, consumption of higher-value food commodities increases (Pingali, 2007). This is particularly true for packaged foods, which are accessible, have low perishability, is cost efficient, and present product information that attracts growing middle classes that are both educated and working in formal occupations (Gulati, Minot, Delgado \& Bora, 2005). As domestic industries within these economies grow to meet diversifying consumer demands, there is an observed positive correlation between the value addition of food processing and GDP per capita growth (Stuckler, McKee, Ebrahim \& Basu, 2012).

In Southeast Asia in particular, the growth of the F\&B industry reflects changing consumer behavior in response to income growth for many and the emergence of an urban class with strong purchasing power. The simultaneous development of the food processing and packaging sectors is thus a necessity for most countries and regions experiencing GDP growth, as is the case with Southeast Asia (Manalili, Dorado, \& Otterdijk, 2011). While individual countries have attracted both intra-regional and extra-regional investment, Southeast Asia induced its own internal success in regional manufacturing capacity through reducing inventories and improving efficient consumer response. For small and medium sized firms involved in F\&B production, reducing inventory times through inventory centralization has resulted in sustained levels of working capital - the day-to-day trading operations calculated as the current assets minus current liabilities-which reduces the savings constraints that these businesses typically experience (Davis, Lockwood, Pantelidis \& Alcott, 2013). Producers that influence the supply chain via efficient 
customer response can reduce opportunity loss, inventory level, and overall cost, as well as increase profitability by sharing the purpose of customer satisfaction (Zenjiro, 1998).

Long before the establishment of ASEAN, Southeast Asia, has been regarded as a developing region of the world. Various consumer studies note that less-developed countries tend to receive negative consumer attitudes about their F\&B products, especially with respect to health benefits (Bilkey \& Nes, 1982; Kanyak, Kucukemiroglu, \& Hyder, 2000; Guenther, Saunders, Dalziel, Rutherford \& Driver, 2015). Compared to the well-developed and well-branded regions of the European Union and North America through the North American Free Trade Agreement, Dinnie, Melewar, Seidenfuss and Musa (2009) note that the problem that ASEAN has in branding itself is that its regional brand "lies in finding successful strategies for projecting a unified brand for what is in reality an association of nations at very different stages of economic development." Cayla and Eckhardt (2007) argue that countries need to capitalize on their local cultural capital to create unique value. Alden, Steenkamp and Batra (1999) assert that globalization has enabled regional brands to be a strong force in international marketing, especially as global consumer culture grows and transcends national boundaries.

The purpose of this research is to determine which factors influence attitude, behavior, and satisfaction in the market in order to discover the implications that these findings will have on Southeast Asian food and beverage producers and exporters. The main objective of this agreement was to strengthen and enhance economic, trade and investment cooperation and to progressively liberalize and promote trade in goods and services as well as create a prosperous investment regime. For the purposes of this thesis, the products referred to in the study are any packaged food product originating from Southeast Asia. This excludes imported loose produce, meats and seafood. In recent years, Southeast Asia has shown progressive growth in the expansion of its food and beverage industry. This study developed its research questions as follows: i) how do beliefs about food and beverage products from Southeast Asia affect attitude; ii) how do consumers consider the influence of family and society in their attitude formation towards food and beverage products from Southeast Asia; iii) how does attitude towards Southeast Asian food and beverage products affect the level of satisfaction for consumers with previous purchasing experience; iv) how does attitude towards Southeast Asian food and beverage products affect behavioral intention; v) how does behavioral intention affect the level of expected satisfaction for those consumers with no prior purchasing experience; and vi) which product subcategories within the food and beverage industry are consumers most likely to buy.

\section{LITERATURE REVIEW}

\subsection{Country of Origin Effect, Country Image, and Country Origin Image}

Country of origin and its effect on consumer behavior has been extensively explored in marketing and trade. Anderson and Cunningham (1972) redefined consumption as a socially conscious action. Gaedeke (1973) found that despite many developing countries exporting products through their comparative advantages, British consumers held negative views about products originating from the least developed countries. Shimp (1984) was among the first to take a causal empirical approach to the variance in consumer behavior towards country of origin and conceptualize consumer ethnocentrism. The foundational work of Shimp has been followed by the work of Brodowsky (1998) who, like Shimp, found that consumers with high ethnocentricity evaluated foreign-made vehicles negatively.

Country image is an early concept, not just limited to marketing, wherein an image of a country is constructed based on multiple dimensions. According to Bannister and Saunders (1978), country image is a generic construct, consisting of "generalized images created not only by representative products but also by the degree of economic and political maturity, historical events, relationships, culture and traditions, and the degrees of technological virtuosity and industrialization." This broad definition is echoed by other authors such as Martin and Eroglu (1993), who define country image as "the total of all descriptive, inferential and informational beliefs one has about a particular country." According to Han (1989), consumers use country image when evaluating products because they "often are unable to detect the true quality of a country's products before purchase." Previous authors who have focused primarily on consumption see the country image as a cognitive process of substituting unattainable information about the product with images of the country to make inferences about quality (Huber \& McCann, 1982; Monroe, 1976; Dodds, Monroe \& Grewal, 1991). 
Roth and Romeo (1992) asserted that country of origin image arises from the stereotypes of a country which informs beliefs about the country's products. Lin and Chen (2006) also deeply explore country of origin image and conclude that it is formed through economic development, political background, level of industrialization, technology development, historical factors and tradition. This image gives rise to stereotypes that consumers relate to in order to evaluate products from a given country. As both country image and country of origin image have arisen in marketing studies to explain consumer behavior in the globalized market, so too has the concept of country branding to explain the processes by which countries create their own brands in order to propagate their agendas.

This study posits that country branding is an important concept to explore when discussing the implications of developing countries having poor images and looking for solutions. Arnholt (2002) describes the possible actions countries could take to build and exploit their country image and country of origin images through country branding and rebranding. According to Arnholt (2002), country branding is an important gateway to see multidimensional growth: positive images of a country leads to higher consumption of its products; higher consumption of products leads to higher willingness to travel (tourism); higher willingness to travel leads to more investment.

\subsection{Food and Beverage Product Attributes}

Among the many beliefs about products within the field of marketing and consumer studies, this research concentrates on consumer beliefs about the external and internal factors of quality, trustworthiness, health benefits, availability and price. These factors are the most practical from an industry perspective in terms of being addressed in the production chain management and through marketing strategies and policy.

\subsubsection{Quality}

Quality is considered the most difficult consumer product attribute to define. According to Ophuis and van Trijp (1995), quality is "synonymous with innate excellence and cannot be analyzed, but only recognized through experience." Zeithaml (1988) takes a more practical approach to measuring quality as the comparative testing of products to measure conformance to standards and superiority in production. Aaker (1991) posits that quality is measured by the consumer's own personal judgments. By this definition, the consumer identifies the intended purpose for the product and personally assesses the product's ability to fulfil its purpose relative to alternatives.

For the F\&B industry, quality is an ongoing judgement that changes before and after consumption; therefore, packaged and processed products like those that pass through the $\mathrm{F} \& \mathrm{~B}$ industry provide consumers with informative and alluring packaging to persuade the prospective buyer prior to the customer forming a post-consumption belief about quality (McDaniel \& Baker, 1977). According to Grunert (2005), quality has an objective and subjective dimension: objective within respect to the physical qualities of the product that producers typically aim to produce; subjective with respect to the quality perceived by the consumers. The evaluation of quality is inferred from the extent that the problem - the hunger/need for nutrition — is solved by the product (Zanoli \& Naspetti, 2002; Reynolds \& Whitlark, 1995).

\subsubsection{Trustworthiness}

Consumer trust has become a central issue in the food chain that links producers to consumers (Yee, Yeung, \& Morris, 2005; Lobb, 2005; Chen, 2008) and is an important factor influencing consumer behavior (Bredahl, 2001; Yee et al. 2005; Schiffman, O'Cass, Paladino \& Carlson, 2013). For the last three decades, food markets in developed countries have been alarmed by food scares and crises, which have brought to light the lack of consumer trust within the food chain. New technologies used within the food sector, along with increasingly globalized trade networks, have revived consumers' interest in food production. As a consequence for food products in the F\&B industries, failure rates are high for new products, causing producers to speculate about the "rumors about the falling brand loyalty [which] have raised the question of whether consumers have become unpredictable or whether they just passively accept the choices that retailers make for them" (Grunert, 2002).

The F\&B industry focused on profit growth and cost reduction to improve efficiency and competitiveness through new production inputs. According to Fischler (1988), modern food has become an unidentified edible object in the eyes of an eater, devoid of origin or history, with no respectable past — in short, without identity. Thus, consumers are 
increasingly trying to determine food attributes and their credence properties - the properties that cannot be determined even after consumption such as long-term health effects - as food production technology evolves to make food attributes highly difficult to understand (Chen, 2008). As a crucial issue in the food chain, the importance of trust extends throughout the linkages in the food chain, from farmers and manufactures as well as to retailers and regulatory institutions (Chen, 2008). Taking into account the ramifications of losing consumers, trust, exploring that as a belief component is important for marketers in measuring their product's brand value.

\subsubsection{Health Benefits}

Towards the end of the 1990s, new marketing rhetoric about the functionality of food led to a greater increase in studies on the perceived utility consumers get from food purchases in terms of long-lasting health effects. Contrasting studies showed that consumers are willing to compromise taste and price of a product if the consumer believes certain health benefits will be gained (Westrate, Van Poppel \& Verschuren, 2002; Menrad, 2003; Jones \& Jew, 2007). Previous studies (Gilbert, 2000; Cox, Koster, \& Russell, 2004) found that consumers were not willing to give up immediate cues such as taste and price for long term health benefits.

In the F\&B industry, consumers have traditionally been concerned about chemical residues, irradiation processes (a safety process commonly misunderstood by consumers) and food additives (e.g., colorings, preservatives, flavorings, artificial sweeteners) to which foods passing through this industry are subjected (Ott, Huang, \& Misra, 1991; Lee, 1989; Bánáti, 2002). According to Baker (2003), consumers tend to acknowledge the technological functions of irradiation and additives, yet fear of the long-term health effects of consuming products treated by these processes continues to be a large factor in consumer behavior. According to Buzby (2001), food safety risks associated with international trade and mass production include: "veterinary drug and pesticide residues, food additives, pathogens (i.e., illness-causing bacteria, viruses, parasites, fungi, and their toxins), environmental toxins such as heavy metals (e.g. lead and mercury) and persistent organic pollutants (e.g. dioxin), and unconventional agents such as prions associated with bovine spongiform encephalopathy in cattle." With increasing incidents of outbreaks of food-borne illnesses in market-chains, consumers in developed markets with high levels of imports tend to consider the immediate and future health effects of consumption (Kim, 2012).

\subsubsection{Availability}

Consumer patterns tend to follow changes in diet and income during varying stages of economic development. Diets are consistently changing, and the impact of globalization has caused the demands of globalized consumers to extend outside of the traditional seasonal periods of their domestic countries and varying price elasticities for products that appeal to globalized palate (Baldwin \& Jones, 2013). Building upon these demands, the succession of trade agreements has significantly impacted consumer behavior, by promoting the diversification of products in markets and expanding their availability and variety. This has resulted in a consumer base that increasingly assesses its consumer power by observing the range and availability of products in their market and thus availability becomes a desired attribute of products (Nzaku, Houston, \& Fonsah, 2010).

Krugman (1979) and his foundational work on trade theory posited that countries could gain from trade through the creation of variety to benefit both producers and exporters. International trade has led to a large diversification of markets which traditionally had evolved more slowly in terms of product variety and availability. Product variety can be observed through many channels, and as Broda and Weinstein (2004) note, variety is "commonly defined as a brand produced by a firm, the total output of a firm, the output of a country, or the output within an industry within a country." As the diversification of goods has come accompanied globalization, international trade becomes a process in which new markets can observe cross-cultural interactions vis-à-vis other countries' consumable goods entering, emphasizing the role of variety in the values of consumers (Eckhardt \& Mahi, 2004).

Today, developed markets no longer recognize one fixed assortment of consumer goods; instead, consumers are accustomed to a wide array of goods that enter and exit (Warde, Martens, \& Olsen, 1999). According to Corneo and Jeanne (1997), product variety serves a function for conspicuous consumers. In developed markets, product variety and availability allows consumers to act in an agentic way in order to both shape market preferences while themselves being influenced by the composition of the market (Eckhardt \& Mahi, 2004). Liberalization of emerging economies 
has also diversified the demands of consumers in developing countries as well; however, as Applebaum (1998) notes, consumer agency is limited due to lower product variety, with only elite classes showing high consumer agency.

\subsubsection{Price}

According to Lichtenstein, Ridgway and Netemeyer (1993), prices are unquestionably one of the most direct and important cues present in the marketplaces: "The pervasive influence of price is due, in part, to the fact that the price cue is present in all purchase situations and, at a minimum, represents to all consumers the amount of economic outlay that must be sacrificed in order to engage in a given purchase transaction." Consumers tend to be highly reactive to pricing: a price increase can discourage purchase for some, while for others, it may function as an indicator of quality and increase purchase probability (Erickson \& Johansson, 1985; Zeithaml, 1988; Dodds \& Monroe, 1985; Ofir, 2004).

Market protectionist policies traditionally removed the competiveness of imports through the introduction of tariffs and quotas, seemingly allowing fair (or, in many cases, unfair) competition between domestic goods and imports; however, this policy is increasingly becoming antiquated as it counteracts the tenets of globalization and concurrent free trade agendas (Scheve \& Slaughter, 2007). Hulland, Todino and Lecraw (1996) found that price premiums increased for products from highly industrialized countries, while those from emerging markets and least-developed countries suffered a counter effect. Thus, pricing is linked to such concepts as country of origin affect, country of origin image, and country brand in which consumers use country of origin and a cue (see Dodds, Monroe, \& Grewal, 1991; Agrawal \& Kamakura, 1999; Drozdenko \& Jensen, 1991).

\subsection{Conceptual Framework}

The Theory of Reasoned Action is an early model developed by Martin Fishbein and Icek Ajzen (1977) that explains the relationship between attitudes and behaviors in human psychology. Ajzen and Fishbein (1980) suggest that subjective norms are the perceived social pressures to which an individual responds in terms of whether they will perform an action (behavior). The theory has been applied to different acts of consumer behavior, namely coupon usage and the social stigma that coupon users face as a subjective norm, as well as brand loyalty and which variables in the attitude attribute to acts of brand loyalty (Shimp, 1984; Ha, 1998). The Theory of Reasoned Action was the predecessor to the more comprehensive Theory of Planned Behavior, also formulated by Ajzen and Fishbein (1980). Under the model, Ajzen and Fishbein (1980) posit that individuals will perform a behavior when they formulate positive beliefs about the action and then are reaffirmed in those beliefs by those important to them. Under the model's parameters, factors affecting intention are personal and reflective of the society around the subject (Ajzen \& Fishbein, 1980). When a situation of conflict between attitude toward the behavior and subjective norms occurs, exploration of how these factors affect one's intention must be conducted to ascertain the relative importance of the attitudinal and normative factors as determinants of intentions. (Ajzen \& Fishbein, 1980). Subjective norms through social influence are regarded as strong predictors of consumer attitude and behavior (Neighbors, Lee, Lewis, Fossos \& Larimer, 2007). Moreover, the degree of homogeneity a society has tends to intensify the degree to which subjective norms influence behavior (Hechter \& Dieter, 2001). According to Diener, Gohm, Suh and Oishi (2000), the subjective norm sensitivity of unmarried consumers is lower than that of those who are married. Moreover, Ajzen (1985), the pioneer of subjective norms in consumer behavior, found a correspondence between the number of children and household size with subjective norm influence.

The ABC Model (Ostrom, 1969) is an early model that explores the process of attitude formation and assumes that attitude is comprised of three components: affective, behavioral and cognitive. Ostrom (1969) also defines attitude as a learned predisposition to respond in a consistent evaluative manner toward an object or class of objects. The model also acknowledges that other factors besides attitude will influence behavior and thus promotes the exploration of normative and situational pressures beyond what was posited under Ajzen and Fishbein's Theory of Reasoned Action and Theory of Planned Behavior (Norman, 1975).

\section{HYPOTHESIS DEVELOPMENT}

The proposed model (Figure 1) for this research adopts the principle of cognitive beliefs affecting attitude from the $\mathrm{ABC}$ model. In addition to cognitive beliefs, the proposed model adopts the factor of subjective norms from the Theory 
of Reasoned Action and Theory of Planned Behavior. Subjective norms, unlike the original theories from which they stem will be tested for their effect on attitude within the proposed model rather than as a component of attitude. Because the study concerns F\&B products, the influence of behavioral controls from the original theory was excluded from the proposed model; it is assumed under the model that most consumers have a reasonable amount of control on their food purchasing behavior and that they are only influenced by subjective norms through societal/family influences on their attitude. The proposed model then incorporates the effects of attitude on behavior, extensively used in psychological studies to determine the predictive power of attitude. The model then finally incorporates the two components of satisfaction and expected satisfaction, which will provide data for exporters to project loyalty levels and customer satisfaction, which is in turn crucial for successful export.

Figure 1. Proposed Model of Research:

A Framework of the Determinants of Attitude, Behavior, and Satisfaction Towards Purchasing Food and Beverage Products.

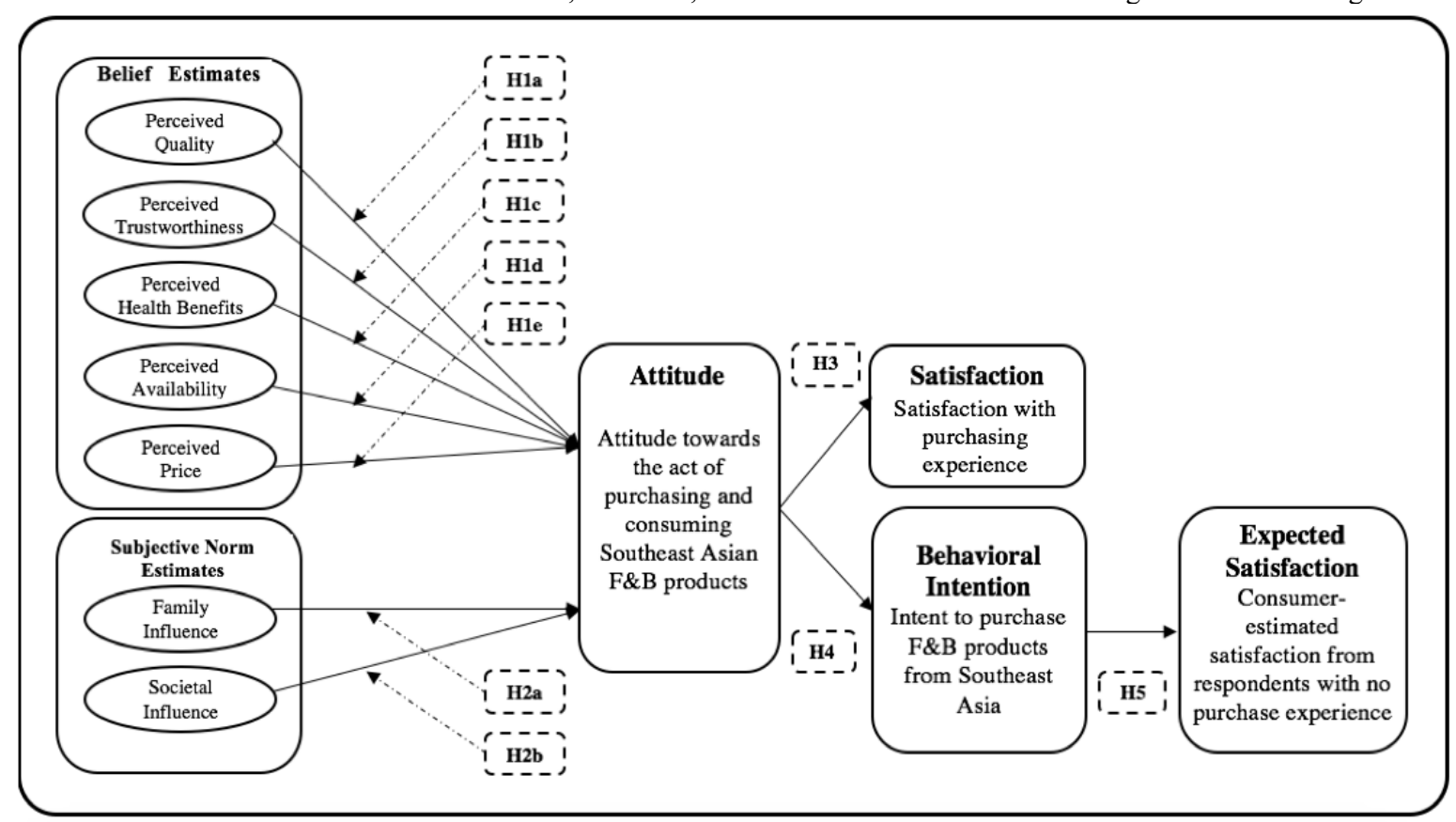

\subsection{Effects of Belief Estimates on Attitude Formation}

Popular marketing models of the 1970s and 1980s often accept the role of beliefs in attitude formation for consumers (Wilkie \& Pessemier, 1973; Fishbein \& Ajzen, 1977; Homer \& Kahle, 1988). Beliefs and attitudes are linked within decision-making hierarchies through which beliefs inform attitudes which subsequently inform behavior. According to Underwood (2010), attitudes are a product of affective processes that reflect beliefs attached to certain subcategories and constructs associated with products. This is further reiterated in the earlier modelling of attitude in such models as the Vector Model, the Technology Acceptance Model and the ABC Model (Calder \& Lutz, 1972; Davis, 1989; Eagly \& Chaiken, 1998). For the ABC model in particular, attitude is derived from cognitive components (beliefs) regrading an attitude object. Attitude formation for consumers serves many purposes: utilitarian purposes such as increasing utility or avoiding loss; ego-defensive to protect oneself (e.g. non-smoking attitudes); knowledge, such as simplifying decisions as in brand loyalty; and value-expressive functions to express identities to others (Mowen \& Minor, 2001). This study hypothesized the following:

H1a: Beliefs about the quality of the products affect attitude towards purchase and consumption

H1b: Beliefs about the trustworthiness of the products affect attitude towards purchase and consumption 
H1c: Beliefs about the health benefits of the products affect attitude towards purchase and consumption

H1d: Beliefs about the availability of the products affect attitude towards purchase and consumption

H1e: Beliefs about the price of the products affect attitude towards purchase and consumption

\subsection{Effects of Subjective Norms on Attitude Formation}

As noted in the Ajzen's Theory of Planned Behavior (1985), of which a modification is used in this research, the theory links behavioral intentions with attitudes, subjective norms and behavioral controls. Chang (1998) examined the correlation between subjective norms and attitudes towards behavior more thoroughly and explained this link as a result of the social environment's influence on attitude formation. Social environments such as family influence attitudes of consumers, who must consider "family food choices" and collective consumption shared among households who share an income (Deliza, Rosenthal \& Silva, 2003). This study hypothesized the following:

H2a: Perceived family influence affects attitude towards purchase and consumption

H2b: Perceived societal influence affects attitude towards purchase and consumption

\subsection{Effects of Attitude on Satisfaction}

User experience entails a test of expected outcomes from the product. The confirmation or disconfirmation of these tests is the point at which consumers derive their levels of satisfaction with the product (Tse \& Wilton, 1988; Cadotte, Woodruft \& Jenkins, 1987; Yi, 1990). From this, the relationship between consumer satisfaction and attitude becomes a reaffirming paradigm in which attitudes inform expected outcomes and where satisfaction from confirmation/disconfirmation of expected outcomes comes to inform post-purchase beliefs (Wirtz \& Bateson, 1999). Satisfaction as a process, is defined by Oliver (1980) as a psychological state resulting from when (dis)confirmation of expectations is coupled with the consumer's preconceived beliefs about the experience. This study hypothesized that attitude affects satisfaction.

H3: Attitude towards Southeast Asian food and beverage products affects satisfaction

\subsection{Effects of Attitude on Behavioral Intention}

The relationship between attitude and behavior has been extensively researched and has generated a vast amount of literature. The field of social psychology was originally designed as a means of examining human attitude as the key to understanding human behavior (Bartlett \& Burt, 1933; Lewin, 1939). As the need to understand the antecedents of human behavior evolved, pioneers in psychological modelling such as Fishbein and Ajzen (1975) posited throughout their work that attitude was the strongest predictor of behavior. The models of these scholars have been adopted in the marketing field to explain consumer behavior as actions informed by attitude.

H4: Attitude towards purchasing and consuming Southeast Asian food and beverage products affects behavioral intention

\subsection{Effects of Behavioral Intention on Expected Satisfaction}

Satisfaction, according to Hempel (1977) is defined as the extent to which the benefits expected from consumption are realized by the consumer. Expected satisfaction can therefore be defined as the perceived level of benefits exclusively prior to consumption at the stage before actual satisfaction derivation, as described in Oliver's (1980) the expectancy-disconfirmation framework of satisfaction. In consideration of satisfaction as process that reflects the congruence or confirmation of expected results, this study aims to isolate the expected satisfaction of purchasing Southeast Asian F\&B products by measuring it from those within the sample group who have no prior purchasing experience, nor have they undergone the process of actual satisfaction derivation. 
H5: Intention to purchase Southeast Asian food and beverage products affects the expected satisfaction derived from having no prior purchasing experience

\section{METHODOLOGY}

\subsection{Data Collection}

This research was conducted in order to determine which beliefs influence consumers' attitudes, behavior towards, and satisfaction with Southeast Asian food and beverage products. In order to determine belief constructs underpinning attitudes, behavior, and satisfaction, a survey questionnaire was designed and distributed throughout Korea using both online surveying and in-person surveying in limited areas. This study collected the data from Korea, as Korea ranks highly in terms of market access and ASEAN F\&B exporters would benefit from determining marketing strategies that maximize the sale of their products in the Korean market.

This study collected 136 completed surveys, distributed both online and offline. Offline surveys were distributed to universities, stations, hospitals, etc. From the offline responses, 11 were incomplete. The remainder of the responses were gathered online through public forums such as Naver Café, Daum Café, and Facebook groups, from which 18 were incomplete, giving the response rate a total of 39 offline, 97 online, and 29 incomplete. The response rate was 0.58 for online and 0.23 for offline, with a total combined response rate of $82.5 \%$ out of the total 166 distributed surveys.

\subsection{Research Design}

The research for this paper was conducted using quantitative data. From the data retrieved, marketers in the emerging Southeast Asian F\&B industry may be able to determine the following; i) whether there is viability for entering the Korean market with their products; ii) whether Koreans are aware of Southeast Asian F\&B products; iii) whether Korean respondents are interested in or intend to buy their products; iv) what type of Korean consumer will be their best customer; v) which factors in their F\&B products need to be addressed to attract more consumers in the Korean context; and vi) which subjective-norm aspects underpin consumer opinions. Analysis of the consumer data obtained in this research will be the first step in undertaking key marketing tasks to prepare a marketing plan, developing products and brand, then pricing. The questionnaire uses a seven-point Likert scale (1 Strongly Disagree, 7 Strongly Agree) questions and 'yes/no' questions to produce ordinal, categorical and binominal data to diversify statistical analysis methods. This study developed questionnaire items based on previous studies (Park, Joo, Quiroz, \& Greenfield, 2015; Cho, 2013). The questionnaire included several blocks of question subsets. Among these blocks, the subsets representing the seven belief estimates, attitude, and behavior were rendered into constructs through factor analysis.

\section{DATA ANALYSIS}

The sample group showed an equal balance between male and female respondents with 67 males and 69 females. Although the main platform of survey distribution was online, it was apparent the questionnaire topic was met with disinterest from younger potential respondents. The sampling also was able to gather responses from people in older age brackets $(55-64,65-74,75$ and over). The in-person questionnaires tended to be a preferred option for older respondents in the sample group who tended to seek clarifications about products and the region of Southeast Asia. A majority of respondents in the sample group had a bachelor's degree as their highest educational attainment, followed by high school. Most respondents had an average income between 20 to 40 million won. 
Table 1. Summary of Demographic Statistics

\begin{tabular}{|c|c|c|}
\hline Characteristic & $\begin{array}{c}n \\
(n=136)\end{array}$ & $\%$ \\
\hline \multicolumn{3}{|l|}{ Gender } \\
\hline Male & 67 & 45 \\
\hline Female & 69 & 46.3 \\
\hline \multicolumn{3}{|l|}{ Age } \\
\hline Under 18 years & 3 & 2 \\
\hline $18-24$ & 18 & 12.1 \\
\hline $25-34$ & 49 & 32.9 \\
\hline $35-44$ & 34 & 22.8 \\
\hline $45-54$ & 13 & 8.7 \\
\hline $55-64$ & 12 & 8.1 \\
\hline $65-74$ & 5 & 3.4 \\
\hline 75 and over & 2 & 1.3 \\
\hline \multicolumn{3}{|l|}{ Marital Status } \\
\hline Unmarried & 78 & 52.3 \\
\hline Married/In partnership & 58 & 42.6 \\
\hline \multicolumn{3}{|l|}{ Education } \\
\hline High School & 34 & 22.8 \\
\hline Two-year college & 10 & 6.7 \\
\hline Bachelors & 75 & 50.3 \\
\hline Masters & 14 & 9.4 \\
\hline Doctorate & 3 & 2 \\
\hline \multicolumn{3}{|l|}{ Income } \\
\hline Under $19,990,000$ won & 26 & 17.4 \\
\hline $20,000,000-40,000,000$ won & 49 & 32.9 \\
\hline $40,000,000-60,000,000$ won & 14 & 9.4 \\
\hline $60,000,000-80,000,000$ won & 6 & 4 \\
\hline $80,000,000-100,000,000$ won & 4 & 2.7 \\
\hline $100,000,000$ won and above & 3 & 2 \\
\hline Undisclosed & 23 & 15.4 \\
\hline \multicolumn{3}{|l|}{ Household Size } \\
\hline 1 & 31 & 20.8 \\
\hline 2 & 27 & 18.1 \\
\hline 3 & 33 & 22.1 \\
\hline 4 & 40 & 26.8 \\
\hline 5 and above & 5 & 3.4 \\
\hline
\end{tabular}

To test the internal consistency of each variable within the proposed model, Cronbach's alpha was employed to derive reliability coefficients. For the belief components, the five proposed variables all showed high internal consistency as extracted factors. This study found Cronbach alpha of 0.84 for perceived quality, 0.85 for perceived trustworthiness, 0.77 for perceived health benefits, 0.80 for perceived availability, and 0.85 for perceived price. For the subjective norms, this study found Cronbach alpha of 0.75 for perceived family influence and 0.73 for perceived societal influence. This study also found Cronbach alpha of 0.86 for attitude and 0.81 for behavioral intention.

\subsection{Test of Hypotheses}

Factor analysis was used to check the validity of the major proposed constructs. With Principal Components Analysis as the extraction method and Varimax Rotation as the rotation method, a total of 43 items were used to extract ten factors. This study applied factor score regression analysis. Table 2 shows the results of multiple regression for effects of beliefs estimates on attitude towards F\&B products. 
Table 2. Effects of Belief Estimates on Attitude

\begin{tabular}{|c|c|c|c|c|}
\hline Factor & B & $\boldsymbol{\beta}$ & $t$ & Sig. (p) \\
\hline \multirow{2}{*}{ Perceived quality } & 0.156 & 0.154 & 2.012 & $.046^{* *}$ \\
\hline & $(0.077)$ & & & \\
\hline \multirow{2}{*}{$\begin{array}{l}\text { Perceived } \\
\text { trustworthiness }\end{array}$} & 0.426 & 0.418 & 5.666 & $.000^{* * *}$ \\
\hline & $(0.075)$ & & & \\
\hline \multirow{2}{*}{ Perceived health benefits } & 0.021 & 0.020 & 0.266 & .791 \\
\hline & $(0.079)$ & & & \\
\hline \multirow{2}{*}{ Perceived availability } & 0.104 & 0.101 & 1.416 & .159 \\
\hline & $(0.073)$ & & & \\
\hline \multirow{2}{*}{ Perceived price } & 0.302 & 0.297 & 3.686 & $.000 * * *$ \\
\hline & $(0.082)$ & & & \\
\hline
\end{tabular}

A multiple linear regression was performed utilizing attitude towards purchasing Southeast Asian F\&B products as the dependent variable and perceived quality $\left(x_{1}\right)$, perceived trustworthiness $\left(x_{2}\right)$, perceived health benefits $\left(x_{3}\right)$, perceived availability $\left(x_{4}\right)$ and perceived price $\left(x_{5}\right)$ as predictors in order to determine if attitude scores could be predicted as a function of these belief estimates. ANOVA results showed that overall, the effect of the belief estimates on attitude was significant at alpha $=0.01$ with $F=64.678$, and $R^{2}=.708$. This study found that perceived trustworthiness, perceived price, and perceived quality are shown to have significant relationships towards attitude. Therefore, H1a, H1b and H1e were accepted.

Table 3 shows the effects of subjective norms on attitude towards F\& B products. ANOVA results show that overall, the effect of the subjective norm estimates on attitude was significant at alpha $=0.01$ with $F=105.095$ and $R^{2}=.610$ Therefore, $\mathrm{H} 1 \mathrm{~b}$ and $\mathrm{H} 1 \mathrm{e}$ were accepted. The results of multiple regression show that perceived family and perceived societal influences affect attitude. Therefore, $\mathrm{H} 2 \mathrm{a}$ and $0 \mathrm{H} 2 \mathrm{~b}$ were accepted.

Table 3. Effects of Subjective Norm Estimates on Attitude

\begin{tabular}{|c|c|c|c|c|}
\hline Factor & B & $\boldsymbol{\beta}$ & $t$ & Sig. (p) \\
\hline \multirow{2}{*}{$\begin{array}{l}\text { Perceived family } \\
\text { influence }\end{array}$} & 0.464 & 0.460 & 6.319 & $.000 * * *$ \\
\hline & $(0.073)$ & & & \\
\hline \multirow{2}{*}{$\begin{array}{l}\text { Perceived societal } \\
\text { influence }\end{array}$} & 0.397 & 0.399 & 5.477 & $.000 * * *$ \\
\hline & $(0.073)$ & & & \\
\hline
\end{tabular}

*** Significant at $\mathrm{p}<0.01$

Table 4 shows the effects of attitude on satisfaction. ANOVA results showed that overall, the effect of attitude on satisfaction was significant at alpha $=0.01$ with $F=14.842$ and $R^{2}=0.13$. The results of regression analysis show that attitude affects satisfaction. Therefore, H3 was accepted.

Table 4. Effects of Attitude on Satisfaction

\begin{tabular}{l|c|c|c|c|}
\hline \multicolumn{1}{|c|}{ Factor } & B & $\boldsymbol{\beta}$ & t & Sig. (p) \\
\hline Attitude towards & 0.545 & 0.378 & 3.853 & $.000^{* * *}$ \\
\hline purchasing & $(0.142)$ & & & \\
\hline$* * *$ Significant at $\mathrm{p}<0.01$ & & & & \\
\hline
\end{tabular}

*** Significant at $\mathrm{p}<0.01$

Table 5 shows the effects of attitude on behavioral intention. ANOVA results show that overall, the effect of attitude on satisfaction was significant at alpha 0.01 , with $F=195.465$, and $R^{2}=0.60$. The results of regression analysis show that attitude affects intention to purchase. Therefore, $\mathrm{H} 4$ was accepted. 
Table 5. Effects of Attitude Towards Behavioral Intention to Purchase

\begin{tabular}{l|c|c|c|c}
\hline \multicolumn{1}{|c|}{ Factor } & B & $\boldsymbol{\beta}$ & $\boldsymbol{t}$ & Sig. (p) \\
\hline $\begin{array}{l}\text { Attitude towards } \\
\text { purchase }\end{array}$ & 0.760 & 0.776 & 13.981 & $.000^{* * *}$ \\
\hline
\end{tabular}

*** Significant at $\mathrm{p}<0.01$

Table 6 shows effects of behavioral intention on expected satisfaction. ANOVA results show that overall, the effect of satisfaction on expected satisfaction is significant at alpha 0.01 , with $F=3.081$ and $R^{2}=0.06$. The results of regression analysis show that behavioral intention does not affect expected satisfaction. Therefore, H5 was rejected.

Table 6. Regression Analysis to Estimate the Effects of Behavioral Intention on Expected Satisfaction

\begin{tabular}{|c|c|c|c|c|}
\hline Factor & B & $\beta$ & $t$ & Sig. $(p)$ \\
\hline \multirow{2}{*}{$\begin{array}{l}\text { Behavioral intention of } \\
\text { purchasing }\end{array}$} & 0.479 & 0.296 & 1.755 & .089 \\
\hline & $(0.273)$ & & & \\
\hline
\end{tabular}

\subsection{Additional Analyses}

With the estimates of subjective norms of perceived family influence and perceived societal influence both showing significance of alpha $=001$ on attitude towards Southeast Asian food and beverage products, further exploration through analysis of co-variance between demographic factors such as household size and marital status was conducted to strengthen the findings of this research.

An ANCOVA of between-subjects factor of household size and covariate of marital status revealed no significant effects of household size on perceived societal influence $(F(4,125)=.208, p=.934)$. Marital status showed a significant main effect $(F(1,125)=23.464, p=.000)$ without interaction between household size and marital status $(F(4,125)=$ $.120, p=.975)$. The partial eta squared value of household size $\left(\eta^{2}=.007\right)$ indicates that a minute $0.7 \%$ of variance is accounted for by household size. For marital status $\left(\eta^{2}=.107\right)$, a much higher $10.7 \%$ of variance is explained by the covariate. The interaction between marital status and household size $\left(\eta^{2}=.004\right)$ shows a minor amount of variance.

From the results, the marital status accounts for approximately $7.5 \%$ of the total variance in perceived family influence on purchasing decisions of food and beverage products (the dependent variable). As a weak effect size, the substantive significance is low. Despite the findings, in Figure 2, the distance between mean scores of those who are unmarried and those who are married displays significance of the analysis of co-variance (a higher mean score indicating a lower level of family influence). 
Figure 2. Estimated Marginal Means for Perceived Family Influence, Controlled for Marital Status, on Perceived Family Influence

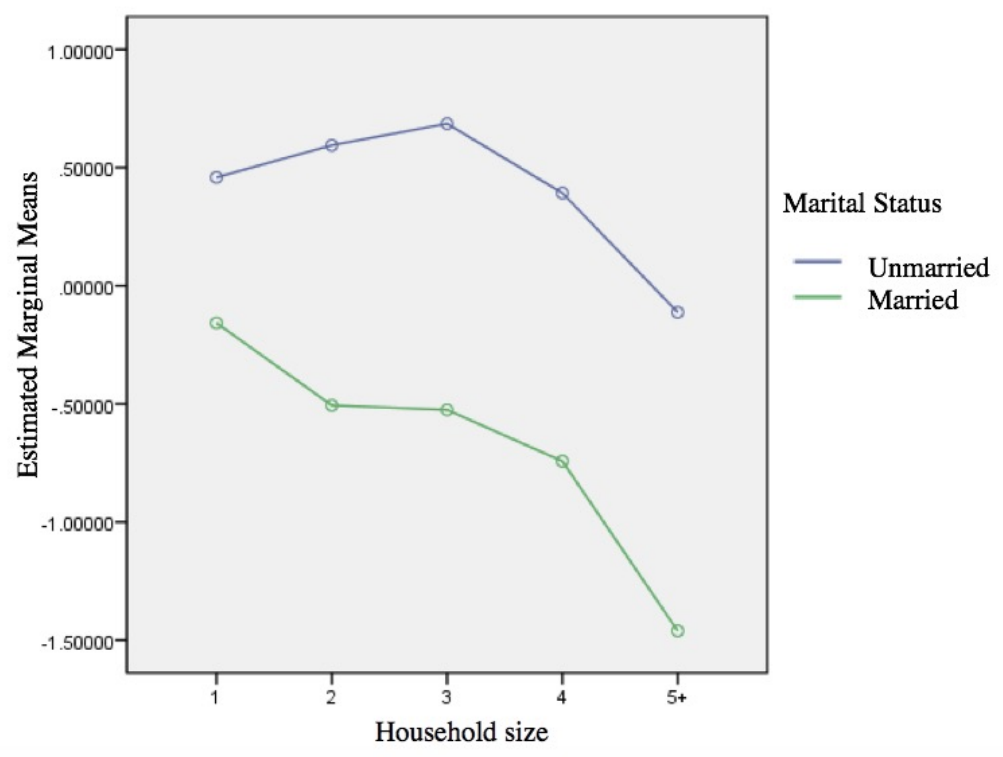

An ANCOVA of the between-subjects factor of household size and covariate of marital status revealed no main effects of household size on perceived societal influence, $(F(4,126)=1.927, p=.110)$. Marital status showed a significant main effect $(F(1,126)=11.457, p=.001)$ without interaction between household size and marital status $(F(4,126)=$ $2.145, p=.079)$. The partial eta squared of marital status showed considerable variance $\left(\eta^{2}=.083 / 8.3 \%\right)$. The interaction between household size and marital status showed variance at $\left(\eta^{2}=.064 / 6.4 \%\right)$. Interestingly, the partial eta squared of household size, despite being insignificant, had the highest variance $\left(\eta^{2}=.58 / 58 \%\right)$. With $\omega^{2}$ equal to only $2.2 \%$ of variance, the effect of household size is weak. Despite the weak effect size and significance of only marital status on perceived family societal influence, Figure 3 displays demonstrative of a diverging level of mean scores between household sizes and those who are married and unmarried. An interpretation of the figure could conclude that married respondents from large households are the most influenced by society in their attitude towards Southeast Asian F\&B products, while by contrast, unmarried respondents from large households showed the lowest level of perceived societal influence (high estimated marginal mean). 
Figure 3. Estimated Marginal Means for Household Size, Controlled for Marital Status, on Perceived Societal Influence

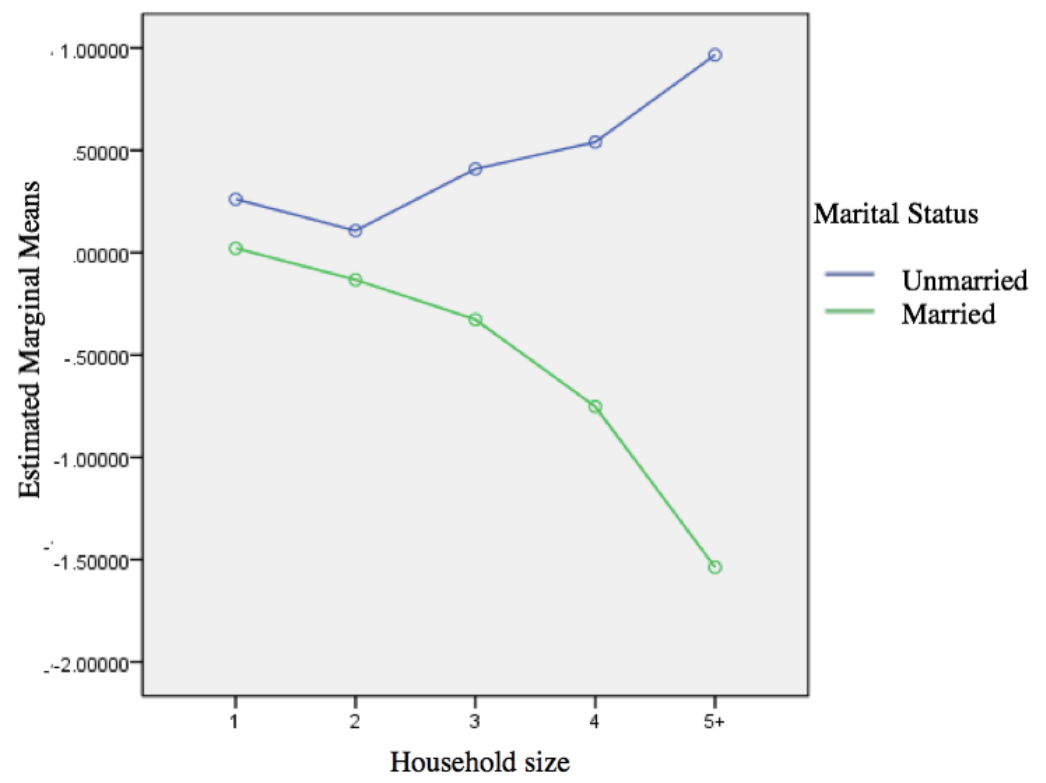

\section{CONCLUSION}

\subsection{Findings and Implications}

The regression analysis of the belief estimates on attitude showed varying results. Perceived quality was shown to have a significant relationship with attitude formation. This finding largely confirms contemporary export guides about the Korean market, which state that Korean consumers are constantly demanding better quality products (Chung, Pysarchik \& Hwang, 2009). Likewise, perceived trustworthiness of the producer and product was shown to have high significance in forming attitude towards a product. The results of this study showed that perceived health benefits of a product do not have a strong relationship with attitude formation. The explanation behind this may be that that health foods are a well-established niche market, and thus they elicit a different process of attitude formation and willingness to purchase from consumers. The findings are reflective of general food and beverage products, of which health foods are a subcategory. Availability was shown to also have a significant relationship to attitude formation. This is further supported by literature showing that consumers who see availability of products at multiple retail platforms as a desirable trait in forming loyalty to a product (Raj, 1985; Alhabeeb, 2007). This finding also contradicts the theory of consumer ethnocentrism which posits that the presence of foreign brands instills a heightened loyalty to domestic brands and increases aversion to foreign products (Shimp, 1984; Watson \& Wright, 2000; Cheng \& Chen, 2004). Lastly, perceived price was shown to be significant on attitude formation as well. Price has the largest existing body of literature regarding its influence on consumer behavior among all the estimates (Erickson \& Johansson, 1985; Zeithaml, 1988; Dodds \& Monroe, 1985; Ofir, 2004).

The subjective norm estimates were based on Ajzen's Theory of Planned Behavior and applied to the Korean context, which strongly values family and society through the influences of both Confucianism and ethno-cultural homogeneity. Perceived family influence about food purchasing was shown to be significant in attitude formation in the sample group. This was further explored in an additional analysis of co-variance, which showed that marital status influences perceived family influence, with married people having lower mean scores meaning stronger family influence. In addition, it can be concluded that unmarried consumers living in smaller households are less likely to be influenced by family in their attitude formation towards purchasing Southeast Asian food and beverage products. The estimate of perceived societal influence was also shown to have significance in attitude formation. Further analysis through ANCOVA showed interesting results in that unmarried consumers from large households have the lowest 
levels of perceived societal influence about attitude towards Southeast Asian F\&B products, while married consumers show an increasing perceived influence as their household size increases.

The results of the regression show that attitude has a significant relationship to the satisfaction that consumers have with purchasing Southeast Asian F\&B products. The findings from the regression between attitude and behavioral intention show that attitude significantly affects intention to purchase Southeast Asian F\&B products. This confirms the Theory of Planned Behavior and the ABC Model, which posit behavior as a function of attitude. From these findings, exporters should thus continue to work on improving consumer attitude through the above mentioned factors in order to increase the intent to purchase. A test between behavioral intention and expected satisfaction was shown to be insignificant. From this, it can be concluded that those with the intention to purchase may not necessarily have a high level of expected satisfaction, nor will those with no intention to purchase have a low level of expected satisfaction. The implication of this finding for exporters is that consumers lack a strong sense of expected satisfaction that would inform their purchasing behavior.

\subsection{Recommendations for Exporters Based on the Study Findings}

From the tested belief estimates within the model, perceived quality, trustworthiness, and price were the most significant factors affecting attitude. F\&B producers in ASEAN are already expecting to see prices decrease as the growing industry increasingly become more effective in production through improvements in inventory times, technological developments, free interregional trade, economies of scale, and supply chain management. Thus, with continuation of production efficiency and price competitiveness, F\&B producers should instead direct their attention towards improving the perceived trustworthiness and quality of products. Among the many avenues of exploration that this study opens up for Southeast Asian F\&B exporters, the subjective norm estimates are of unique significance. Due to the family and societal factors influencing attitude formation about Southeast Asian F\&B products, exporters must also consider how to address variables other than the physical attributes of the products. The analyses of the model showed that the higher the level of perceived family and societal influence, the more negative were the respondents' attitude towards the products.

With the variable of satisfaction with prior purchase confirmed as influenced by attitude in the research, exporters of F\&B products will face challenges in changing consumer attitudes towards their products if they hold negative attitudes. The results show that there is a reaffirming paradigm whereby consumers with a positive attitude will continue to have high satisfaction with the product, while consumers with negative attitudes will continue to have low satisfaction or dissatisfaction if they choose to purchase. The recommended policy action from these findings is that producers should explore the significant estimates which were shown to have a positive effect on attitude from the beliefs component of the model: namely, perceived quality, perceived trustworthiness, and perceived price as mentioned above. By targeting these factors to promote a positive attitude towards Southeast Asian F\&B products, producers can attempt to create stronger positive attitudes and thus also increase level of satisfaction with the purchase. Satisfaction is important for producers as it is a determining factor of loyalty levels that would concretize the presence of the product in the market and sustain sales (Raj, 1985; Biong, 1993; Alhabeeb, 2007).

\subsection{Limitations and Future Research}

The design limitations of this research were that the sample group might have been too specific to use of ASEAN food and beverage exporters. As ASEAN exporters are seeking many different export markets to complement their projected growth, the data from this research is limited to Korean consumers only, and thus the findings can only be used by exporters exploring access to the Korean market. To further fill knowledge gaps for ASEAN and its direct relation to ASEAN +3 countries, it would be advisable to conduct similar studies with Japanese and Chinese consumers to build a stronger evidence base for trade in the East Asian region. Further limitations in the study design are that it uses a composite of multiple theoretical models with different isolations, and this research thus explores attitude, behavior, and satisfaction which is a somewhat cumbersome load of theoretical centers for the model. The findings of this model will, however, be useful for exporters researching these varying factors. Future research should be extended to cross-cultural analysis. Cause and effect analysis using LISREL could be applied to future research. 


\section{AUTHOR BIOGRAPHIES}

Alexander James McSporran is a graduate of the Master of Development Policy program at KDI School of Public Policy and Management. Alexander currently works at the Ministry of Foreign Affairs and Trade in New Zealand and his research interests include food trade and marketing, sustainable development practices and Asia-Pacific regional development. Email: alexmcsporran@gmail.com

Yoon C. Cho is professor at the KDI School of Public Policy and Management. She was professor at Hawaii Pacific University. She has various publications in journals such as Journal of business reserach, Journal of business \& economics research, International business \& economics research journal, etc.

\section{REFERENCES}

Aaker, D.A. (1991). Capitalizing on the value of a brand name, New York: The Free Press, 125-128.

Agrawal, J., \& Kamakura, W.A. (1999). Country of origin: A competitive advantage? International Journal of Research in Marketing, 16(4), 255-267.

Ajzen, I. (1985). From intentions to actions: A theory of planned behavior. Action Control, Berlin-Heidelberg: Springer Series in Social Psychology, 11-39

Ajzen, I., \& Fishbein, M. (1980). Understanding attitudes and predicting Social Behavior, New Jersey: Prentice-Hall.

Alden, D.L., Steenkamp, J-B.E.M., \& Batra, R. (1999). Brand positioning through advertising in Asia, North America, and Europe: The role of global consumer culture. The Journal of Marketing, 63(1), 75-87.

Alhabeeb, M. J. (2007). On consumer trust and product loyalty. International Journal of Consumer Studies, 31(6), 609-612.

Anderson, W. T., \& Cunningham, W. H. (1972). The socially conscious consumer. The Journal of Marketing, 36(3), 23-31.

Applbaum, K. (1998). The sweetness of salvation: Consumer marketing and the liberal-bourgeois theory of needs. Current Anthropology, 39(3), 323-350.

Arnholt, S. (2002). Nation branding: A continuing theme. Journal of Brand Management, 10(1), 59-60.

Baker, G. A. (2003). Food safety and fear: Factors affecting consumer response to food safety risk. International Food and Agribusiness Management Review, 6(1), 1-11.

Baldwin, K. L., \& Jones, K. G. (2013). U.S. citrus import demand: Seasonality and substitution. Journal of International Food \& Agribusiness Marketing, 25(1), 24-41.

Bánáti, D. (2002). Consumer response to food scandals and scares. Trends in Food Science \& Technology, 22(2) 56-60.

Bannister, J. P., \& Saunders, J. A. (1978). United Kingdom consumers' attitudes towards imports: The measurement of national stereotype image. European Journal of Marketing, 12(8), 562-570.

Bartlett, F. C., \& Burt, C. (1933). Remembering: A study in experimental and social psychology. British Journal of Educational Psychology, 3(2), 187-192.

Bilkey, W. J., \& Nes, E. (1982). Country-of-origin effects on product evaluations. Journal of International Business studies, 13(1), 89-100.

Biong, H. (1993). Satisfaction and loyalty to suppliers within the grocery trade. European Journal of Marketing, 27(7), 21-38.

Bredahl, L. (2001). Determinants of consumer attitudes and purchase intentions with regard to genetically modified food-results of a cross-national survey. Journal of Consumer Policy, 24(1), 23-61.

Broda, C., \& Weinstein, D. E. (2004). Variety growth and world welfare. The American Economic Review, 94(2), $139-144$.

Brodowsky, G. H. (1998). The effects of country of design and country of assembly on evaluative beliefs about automobiles and attitudes toward buying them: A comparison between low and high ethnocentric consumers. Journal of International Consumer Marketing, 10(3), 85-113.

Buzby, J. C. (2001). Effects of Food-safety Perceptions on Food Demand and Global Trade, In Changing structure of global food consumption and trade (pp. 55-66). Washington: US Department of Agriculture.

Cadotte, E R., Woodruff, R. B., \& Jenkins, R. L. (1987). Expectations and norms in models of consumer satisfaction. Journal of Marketing Research, 24(3), 305-314.

Calder, B. J., \& Lutz, R. J. (1972). An Investigation of Some Alternatives to the Linear Attitude Model, In SV-Proceedings of the third annual conference of the association for consumer research (pp. 812-815). Chicago, IL: Association for Consumer Research.

Cayla, J., \& Eckhardt, G. M. (2007). Asian brands without borders: Regional opportunities and challenges. International Marketing Review, 24(4), 444-456.

Chang, M. (1998). Predicting unethical behavior: A comparison of the theory of reasoned action and the theory of planned behavior. Journal of Business Ethics, 17(16), 1825-1834.

Chen, M. (2008). Consumer trust in food safety: A multidisciplinary approach and empirical evidence from Taiwan. Risk Analysis, 28(6), 1553-1569. 
Cheng, L., \& Chen, Z. (2004). Consumer ethnocentrism and willingness to buy domestic products in a developing country setting: Testing moderating effects. Journal of Consumer Marketing, 21(6), 391-400.

Cho, H. (2013). Contemporary South Korean society: A critical perspective (vol. 26). London: Routledge.

Chung, J., Pysarchik, D. T., \& Hwang, S. (2009). Effects of country-of-manufacture and brand image on Korean consumers' purchase intention. Journal of Global Marketing, 22(1), 21-41.

Corneo, G., \& Jeanne, O. (1997). Conspicuous consumption, snobbism and conformism. Journal of Public Economics, 66(1), 5571.

Cox, D. N., Koster, A., \& Russell, C. G. (2004). Predicting intentions to consume functional foods and supplements to offset memory loss using an adaptation of protection motivation theory. Appetite, 43(1), 55-64.

Davis, B., Lockwood, A., Pantelidis, I., \& Alcott, P. (2013). Food and beverage management. London: Routledge.

Davis, F. D. (1989). Perceived usefulness, perceived ease of use, and user acceptance of information technology. MIS Quarterly, 13(3), 319-340.

Deliza, R., Rosenthal, A., \& Silva, A. L. (2003). Consumer attitude towards information on non-conventional technology. Trends in Food Science \& Technology, 14(1), 43-49.

Diener, E., Gohm, C. L., Suh, E., \& Shigehiro, O. (2000). Similarity of the relations between marital status and subjective wellbeing across cultures. Journal of Cross Cultural Psychology, 31(4), 419-436.

Dinnie, K., Melewar, T. C., Seidenfuss, K., \& Musa, G. (2009). Member state perspectives on the ASEAN region brand. 3rd International Conference on Destination Branding and Marketing, Institute for Tourism Studies, Macau.

Dodds, W. B. \& Monroe, K. B. (1985). The effect of brand and price information on subjective product evaluations. NA-Advances in Consumer Research, 12(1), 85-90.

Dodds, W. B., Monroe, K. B., \& Grewal, D. (1991). Effects of price, brand, and store information on buyers' product evaluations. Journal of Marketing Research, 28(3), 307-319.

Drozdenko, R., \& Jensen, M. (2009). Translating country-of-origin effects into prices. Journal of Product \& Brand Management, 18(5), 371-378.

Eagly, A. H., \& Chaiken, S. (1998). Attitude structure and function. The Handbook of Social Psychology, 2(4), $269-322$.

Eckhardt, G. M., \& Mahi, H. (2004). The role of consumer agency in the globalization process in emerging markets. Journal of Macromarketing, 24(2), 136-146.

Erickson, G. M., \& Johansson, J. K. (1985). The role of price in multi-attribute product evaluations. Journal of Consumer Research, 12(2), 195-199.

Fischler, C. (1988). Food, self, and identity. Social Science Information, 27(1), 275-293.

Fishbein, M., \& Ajzen, I. (1977). Belief, attitude, intention, and behavior: An introduction to theory and research. Philosophy and Rhetoric, 10(2), 130-132.

Fishbein, M., \& Ajzen, I. (1975). A Bayesian analysis of attribution processes. Psychological Bulletin, 82(2), 261-277.

Gaedeke, R. (1973). Consumer attitudes toward products made in developing countries. Journal of Retailing, 49(2), 13-24.

Gilbert, L. C. (2000). The functional food trend: What's next and what Americans think about eggs. Journal of the American College of Nutrition, 19(5), 507-512.

Grunert, K. G. (2002). Current issues in the understanding of consumer food choice. Trends in Food Science \& Technology, 13(8), $275-285$.

Grunert, K. G. (2005). Food quality and safety: Consumer perception and demand. European Review of Agricultural Economics, 32(3), 369-391.

Guenther, M., Saunders, C., Dalziel, P., Rutherford, P., \& Driver, T. (2015). Maximising export returns: Consumer attitudes towards attributes of food and beverages in export markets relevant to New Zealand. Research Report, Christchurch: Lincoln University.

Gulati, A., Minot, N., Delgado, C., \& Bora, S. (2007). Growth in high-value agriculture in Asia and the emergence of vertical Links with farmers. The World Bank, 98-108.

Ha, C. (1998). The theory of reasoned action applied to brand loyalty. Journal of Product \& Brand Management, 7(1), 51-61.

Han, M. C. (1989). Country image: Halo or summary construct? Journal of Marketing Research, 26(2), 222-229.

Hechter, M., \& Dieter, K. (2001). Social norms. New York: Russell Sage Foundation.

Hempel, D. J. (1977). Consumer satisfaction with the home buying process: Conceptualization and measurement. Marketing Science Institute, 6(1), 7-21.

Homer, P. M., \& Kahle, L. R. (1988). A structural equation test of the value-attitude-behavior hierarchy. Journal of Personality and Social Psychology, 54(4), 638-646.

Huber, J. \& McCann, J. (1982). The impact of inferential beliefs on product evaluations. Journal of Marketing Research, 19(3), 324-333.

Hulland, J., Todiño, H. S., \& Lecraw, D. J. (1996). Country-of-origin effects on sellers' price premiums in competitive Philippine markets. Journal of International Marketing, 4(1), 57-79.

Jones, P. J. \& Jew, S. (2007). Functional food development: Concept to reality. Trends in Food Science \& Technology, 18(7), 387390.

Kanyak, E., Kucukemiroglu, O., \& Hyder, A. S. (2000). Consumers' country-of-origin (COO) perceptions of imported products in a homogenous less-developed country. European Journal of Marketing, 34(9), 1221-1241. 
Kim, R. B. (2009). Meeting consumer concerns for food safety in South Korea: The importance of food safety and ethics in a globalizing market. Journal of Environmental Ethics, 22(2), 141-152.

Kim, R. B. (2012). Consumer attitude of risk and benefits toward genetically modified (GM) foods in South Korea: Implications for food policy. Engineering Economics, 23(2), 189-199.

Krugman, P. R. (1979). Increasing returns, monopolistic competition, and international trade. Journal of International Economics, 9(4), 469-479.

Lee, K. (1989). Food neophobia: Major causes and treatments. Food Technology, 43(12), 62-73.

Lewin, K. (1939). Field theory and experiment in social psychology: Concepts and methods. American Journal of Sociology, 44(6), 868-896.

Lichtenstein, D. R., Ridgway, N. M., \& Netemeyer, R. G. (1993). Price perceptions and consumer shopping behavior: A field study. Journal of Marketing Research, 30(2), 234-245.

Lin, L., \& Chen, C. (2006). The influence of the country-of-origin image, product knowledge and product involvement on consumer purchase decisions: An empirical study of insurance and catering services in Taiwan. Journal of Consumer Marketing, 23(5), 248-265.

Lobb, A. (2005). Consumer trust, risk and food safety: A review. Food Economics: Acta Agriculturae Scandinavica, 2 (1), $3-12$.

Manalili, N., Dorado, M. A., \& Van Otterdijk, R. (2011). Appropriate food packaging solutions for developing countries. Save Food, Study conducted for the International Congress. Rome: Food and Agriculture Organization.

Martin, I. M., \& Eroglu, S. (1993). Measuring a multi-dimensional construct: Country image. Journal of Business Research, 28(3), 191-210.

McDaniel, C., \& Baker, R. C. (1977). Convenience food packaging and the perception of product quality. Journal of Marketing, 41(4), 57-58.

Menrad, K. (2003). Market and marketing of functional food in Europe. Journal of Food Engineering, 56(2), 181-188.

Monroe, K. B. (1976). The influence of price differences and brand familiarity on brand preferences. Journal of Consumer Research, 3(1), 42-49.

Mowen, J. C., \& Minor, M. S. (2001). Consumer behavior: A framework. New Jersey: Prentice-Hall.

Neighbors, C., Lee, C. M., Lewis, M. A., Fossos, N., \& Larimer, M. E. (2007). Are social norms the best predictor of outcomes among heavy-drinking college students? Journal of Studies on Alcohol and Drugs, 68(4), 556-565.

Norman, R. (1975). Affective-cognitive consistency, attitudes, conformity, and behavior. Journal of Personality and Social Psychology, 32(1), 83-91.

Nzaku, K., Houston, J. E., \& Fonsah, E. G. (2010). Analysis of US demand for fresh fruit and vegetable imports. Journal of Agribusiness, 28(2), 163-181.

Ofir, C. (2004). Reexamining latitude of price acceptability and price thresholds: Predicting basic consumer reaction to price. Journal of Consumer Research, 30(4), 612-62.

Oliver, R. L. (1980). A cognitive model of the antecedents and consequences of satisfaction decisions. Journal of Marketing Research, 17(4), 460-469.

Oliver, R. L. (1981). Measurement and evaluation of satisfaction processes in retail settings. Journal of Retailing, 57(3), 25-48.

Ophuis, P., \& Van Trijp, H. C. (1995). Perceived quality: A market driven and consumer oriented approach. Food Quality and Preference, 6(3), 177-183.

Ostrom, T. M. (1969). The relationship between the affective, behavioral, and cognitive components of attitude. Journal of Experimental Social Psychology, 5(1), 12-30.

Ott, S. L., Huang, C. L., \& Misra, S. K. (1991). Consumers' Perceptions of Risks from Pesticide Residues and Demand for Certification of Residue-Free Produce. In Economics of food safety (pp. 175-188). Netherlands: Springer.

Park, H., Joo, J., Quiroz, B., \& Greenfield, P. M. (2015). Sociodemographic factors influence cultural values comparing European American with Korean mothers and children in three settings: Rural Korea, urban Korea, and Los Angeles. Journal of Cross-Cultural Psychology, 46(9), 1131-1149.

Pingali, P. (2007). Westernization of Asian diets and the transformation of food systems: Implications for research and policy. Food Policy, 32(3), 281-298.

Roth, M. S., \& Romeo, J. B. (1992). Matching product category and country image perceptions: A framework for managing country-of-origin effects. Journal of International Business Studies, 23(3), 477-497.

Raj, S. P. (1985). Striking a balance between brand popularity and brand loyalty. The Journal of Marketing, 49(1), 53-59.

Reynolds, T. J., \& Whitlark, D. B. (1995). Applying laddering data to communications strategy and advertising practice. Journal of Advertising Research, 35(4), 9-17.

Schiffman, L., O’Cass, A., Paladino, A., \& Carlson, J. (2013). Consumer behavior. Australia: Pearson Higher Education.

Scheve, K. F., \& Slaughter, M. F. (2007). A new deal for globalization. Foreign Affairs, 86(34), 1-6.

Shimp, T. A. (1984). Consumer ethnocentrism: The concept and a preliminary empirical test. NA-Advances in Consumer Research, $11(1), 285-290$.

Stuckler, D., McKee, M., Ebrahim, S., \& Basu, S. (2012). Manufacturing epidemics: The role of global producers in increased consumption of unhealthy commodities including processed foods, alcohol, and tobacco. Public Library of Science Medical Journal, 9(6), 101-235. 
Tse, D. K. \& Wilton, P. C. (1988). Models of consumer satisfaction formation: An extension. Journal of Marketing Research, 25(2), 204-212.

Underwood, C. (2010). Belief and Attitude Change in the Context of Human Development, In Sustainable development in the twenty-first century vol. II (pp.1-20). Oxford: EOLSS Publications.

Warde, A., Martens, L., \& Olsen, W. (1999). Consumption and the problem of variety: Cultural omnivorousness, social distinction and dining out. Sociology, 33(1), 105-127.

Watson, J. J., \& Wright, K. (2000). Consumer ethnocentrism and attitudes toward domestic and foreign products. European Journal of Marketing, 3(9), 1149-1166.

Weststrate, J. A., Van Poppel, G., \& Verschuren, P. M. (2002). Functional foods, trends and future. British Journal of Nutrition, $88(2), 233-235$

Wilkie, W. L., \& Pessemier, E. A. (1973). Issues in marketing's use of multi-attribute attitude models. Journal of Marketing Research, 10(4), 428-441.

Wirtz, J., \& Bateson, J. E. G. (1999). Consumer satisfaction with services: Integrating the environment perspective in services marketing into the traditional disconfirmation paradigm. Journal of Business Research, 44(1), 55-66.

Yee, W. M., Yeung, R. M., \& Morris, J. (2005). Food safety: Building consumer trust in livestock farmers for potential purchase behavior. British Food Journal, 107(11), 841-854

Yi, Y. (1990). A critical review of consumer satisfaction. Review of Marketing, 4(1), 68-123.

Zanoli, R., \& Naspetti, S. (2002). Consumer motivations in the purchase of organic food: A means-end approach. British Food Journal, 104(8), 643-653.

Zeithaml, V. A. (1988). Consumer price, quality, and value: A means-end model and synthesis of evidence. The Journal of Marketing, 52(3), 2-22.

Zenjiro, I. (1998). Supply chain management, Kogyo: Chosakai. 